\title{
Insight into Graphite Oxidation in a NiO-based Hybrid Direct Carbon Fuel Cell
}

\author{
Cairong Jiang ${ }^{\mathrm{ab}}$, Can Cui ${ }^{\mathrm{a}}$, Jianjun $\mathrm{Ma}^{\mathrm{ab} *}$, and John T. S. Irvine ${ }^{\mathrm{c}}$ \\ a, School of Materials Science and Engineering, Sichuan University of Science and Engineering, Zigong, Sichuan, \\ 643000, P. R. China \\ b. Material Corrosion and Protection Key Laboratory of Sichuan province, Zigong, Sichuan, 643000, P. R. China \\ c, School of Chemistry, University of St Andrews, KY16 9ST, Scotland, United Kingdom \\ *Corresponding author:JM:Email: jima@suse.edu.cn or majanjun@mail.ustc.edu.cn
}

\begin{abstract}
:
A direct carbon fuel cell is an electricity generation device using solid carbon as a fuel directly with no reforming process. In this study, three-carbon fuels, graphitic carbon (GC), carbon black (CB), and biomass carbon $(\mathrm{BC})$ are tested as the fuel to investigate the influence of carbon fuel properties on the cell performance in HDCFC with a traditional nickel oxide as the anode. Either an electrolyte-supported cell with a thin nickel oxide anode or an anode-supported cell with a thick nickel oxide anode is used to evaluate the electrochemical reactivity of carbon samples. These three-carbon fuels are characterised on the crystal structure, particle size, composition, and surface property. It is found that GC shows excellent cell performance on thin nickel oxide anode. However, it displays relatively slow electrochemical reactivity on the thick anode due to its great extent of carbon oxidation. BC shows good initial cell performance but fast degradation of the cell performance, as much more hydrogen is released at the beginning of the cell test. The anode reactions of HDCFCs are explored by the in-situ gas analysis in open circuits and under current load conditions. It is observed that GC produces the highest amount of $\mathrm{CO}$ among these three fuels, suggesting that carbon oxidation is the dominant electrochemical process in HDCFCs after a certain time when most of the hydrogen is released from the pyrolysis process.
\end{abstract}

Key words: Graphite; Carbon fuel properties; Electrochemical oxidation; In-situ gas analysis 


\section{Introduction}

A direct carbon fuel cell is a device that converts the chemical energy of solid carbon into electricity with no external gasification or reforming process [1-3]. In recent years, it receives more attention due to high energy conversion efficiency and its easy availability of the fuel. Solid carbon can be obtained from a variety of natural resources, e. g., forest, agriculture, and food waste [4]. Up to now, so many kinds of carbon fuels have been applied in DCFCs. Researchers have focused on the investigation of the utility of different fuels like pure carbon [5-8], biochar, coal or even raw biomass in a variety of cell configurations, such as molten hydroxides-based DCFCs, molten carbonates-based DCFCs, and solid oxide conductors DCFCs [9-11].

In hydroxide-based DCFC, Hackett et al.[12] evaluated various carbonaceous materials, especially graphite (GC). They investigated the effect of GC rods' fuel structure on the open-circuit voltage and life, and, they also conducted a lifetime comparison.

Weaver et al.[13] presented a molten carbonate electrolyte to be used for direct carbon conversion in 1979. They tested several types of carbon fuels and concluded that devolatilised coal is more reactive than spectroscopic carbon and pyrolytic GC. They linked the high reactivity to the large surface area and the poor crystallisation. The most reactive material, JPL coal, produced $100 \mathrm{~mA} \mathrm{~cm}^{-2}$ at $0.8 \mathrm{~V}$ vs. reference electrode at $700^{\circ} \mathrm{C}$, the potential at $100 \mathrm{~mA} \mathrm{~cm}-2$ increasing to $0.9 \mathrm{~V}$ at $800^{\circ} \mathrm{C}$. Besides, they measured the anode off-gas as $90 \% \mathrm{CO}_{2}$ at a high current density and found the $\mathrm{CO}_{2} / \mathrm{CO}$ ratio decreased at lower current densities. In molten carbonate-based DCFCs, the pore volume and the surface area influence the wettability between the fuel and the molten carbonate, promoting electrochemical reactions in the DCFC system [14]. Chen et al.[15] and Peng et al. [16] have demonstrated that the wetting behaviour of the carbon anode may be as crucial as the molecular mechanism for carbon oxidation in molten carbon DCFCs. Li et al. [17] and co-workers investigated the effects of the chemical and physical properties of fuels such as composition, structure, surface area, and surface functional groups on electrochemical reactions. They found that desirable structure of the carbon fuel for carbonate-based DCFC is to have a high mesoporous surface area and oxygen-rich surface groups [18]. They confirmed that carbon with oxygen-rich surface groups possesses high electrochemical reactivity. They also performed surface modification of activated carbon and carbon particles with acid or air plasma. Similarly, the acid-treated carbon gives the best performance due to the most considerable degree of surface oxygen functional groups [19]. However, Cherepy et al.[20] 
carried out recently a work using eutectic molten carbonate electrolyte for the direct conversion of solid carbon particulates. They found that the surface area has no substantial effects on the carbon discharge rate.

In recent years, significant efforts have been made to study the relationship between the characteristics of the carbon fuel and the performance of the DCFC device [21-23]. Carbon fuel properties are vitally important to the output performance of direct carbon fuel cells (DCFCs). Features such as surface functional groups, surface area, pore structure, the degree of crystallinity have been investigated, and the effects of these parameters on the cell performance have been evaluated.[6] Although the utilisation of carbon in fuel cells has been widely studied, the oxidation mechanism of carbon at the anode is not fully understood. GC is a typical fuel for DCFCs as its graphitic structure. A literature survey demonstrates that GC has been extensively studied and experimentally evaluated as a fuel in a variety of DCFC configurations. In different settings, the carbon oxidation mechanism might change remarkably. Thus, different conclusions were reported. It is said that carbon fuels with a high surface area (e.g., devolatilised coal) are more accessible to the anode reaction than GC.[13] However, Cherepy et al.[20] experimented with various carbon samples in a molten carbonate electrolyte and obtained the best performance of $50 \mathrm{~mA} \mathrm{~cm}^{-2}$ at $0.8 \mathrm{~V}$ on GC carbon, which might be due to its excellent conductivity. Vutetakis et al. [24] reported GC-fuelled molten carbonate-based DCFCs shows better performance than that of an anthracite-fuelled DCFC, but poorer performance than that of a diamondfuelled DCFC. Li et al.[18] carried out a comparative experiment on GC, carbon black, and active carbon in molten carbonate-DCFCs. In their research, GC showed the lowest electrochemical reactivity at different potentials and temperatures, and the peak power density delivered was around $17 \mathrm{~mW} \mathrm{~cm}-2$ at $800{ }^{\circ} \mathrm{C}$, implying low electrochemical activity of the highly ordered GC. Recently, Chen et al. [25] studied the performance of GC as a fuel in DCFC based molten carbonate $\mathrm{Li}_{2} \mathrm{CO}_{3} / \mathrm{K}_{2} \mathrm{CO}_{3} / \mathrm{Al}_{2} \mathrm{O}_{3}$. They concluded that GC alone could not perform well as the anode fuel in DCFC although it has a regular structure, a high electrical conductivity, and a low resistance. Meanwhile, the influence of GC fuel on the performance and lifetime of the DCFC are still up for debate. From the above results, we can see that most research is focused on the molten carbonate DCFCs. The reactivities of GC in hybrid direct carbon fuel cells with a molten carbonate fuel cell and a solid oxide fuel cell is not extensively studied.

We have demonstrated the carbon oxidation process in a hybrid direct carbon fuel cell using carbon black as fuel in our previous research [26]. Our initial investigation on the application of different carbon 
fuels in HDCFCs showed that GC in an anode-supported cell exhibited poor cell performance of $75 \mathrm{~mW}$ $\mathrm{cm}^{-2}$, which is much lower than 100 and $210 \mathrm{~mW} \mathrm{~cm}^{-2}$ at $750^{\circ} \mathrm{C}$ with carbon black and activated carbon as the fuel, respectively [27]. Among all the fuels, biomass carbon (BC, pyrolysed medium density fibreboard) generated the best cell performance with a maximum power density of $878 \mathrm{~mW} \mathrm{~cm}^{-2}$ at 750 ${ }^{\circ} \mathrm{C}[28]$.

In this study, we will carry out further investigation on the key factors affecting the electrochemical reactivity of carbon fuels in the HDCFC system. We will focus on the GC fuel on a thin NiO-electrode and a thick NiO-anode. A standard fuel of carbon black (CB) widely used in other literature and a biomass carbon (BC) [29] are used for comparison regarding the difference in chemical and surface properties. In this paper, for the first time, we investigated the electrochemical oxidation of fuel in the DCFC with in-situ gas analysis under electrochemical test.

\section{Experimental}

\subsection{Pre-treatment of carbon fuels}

The carbon fuels for experiments are graphite carbon (GC, Cabot), carbon black (CB, XC-72R, Cabot), and biomass carbon (BC). The biomass carbon was pyrolysed at $400^{\circ} \mathrm{C}$ in nitrogen. A mixture of 62 mol\% lithium carbonate (Aldrich Chemical Co., WI, USA) and 38 mol\% potassium carbonate (Fisher, UK) was pre-mixed by ball milling in acetone for $24 \mathrm{~h}$ before mixed with different carbons. The weight ratio of carbon to $\mathrm{Li}_{2} \mathrm{CO}_{3}-\mathrm{K}_{2} \mathrm{CO}_{3}$ is $4: 1$. The same process was used for the carbon-carbonate mixture, followed by drying in the oven at $80^{\circ} \mathrm{C}$ for overnight.

\subsection{Cells preparation and electrochemical characteristics}

Electrolyte-supported SOFCs have a configuration of NiO-YSZ layer/YSZ(1 mm)/LSM-YSZ layer. First, a YSZ disk was made by dry pressing and sintering at $1500{ }^{\circ} \mathrm{C}$ for $10 \mathrm{hrs}$. Secondly, an anode layer with a mixture of $\mathrm{NiO}$ and $\mathrm{YSZ}$ in a weight ratio of 60 to 40 was screen printed on one side of the YSZ disk and calcined at $1350{ }^{\circ} \mathrm{C}$ for $2 \mathrm{hrs}$. Thirdly, a composite cathode layer of ( $\left.\mathrm{La}_{0.8} \mathrm{Sr}_{0.2}\right)_{0.95} \mathrm{MnO}_{3-\delta}-\mathrm{YSZ}$ was screen printed on the other side of the YSZ disk and calcined at $1100^{\circ} \mathrm{C}$ for $2 \mathrm{hrs}$. The diameter of the YSZ disk was $20 \mathrm{~mm}$. The diameter of the anode and the cathode was the same, which was 12 $\mathrm{mm}$. The as-prepared cell was painted with silver paste on the anode and the cathode as the current collectors followed by calcined at $800{ }^{\circ} \mathrm{C}$ for $1 \mathrm{hr}$.

Anode-supported SOFCs have a configuration of NiO-YSZ $(1 \mathrm{~mm}) /$ YSZ thin film $(5-10 \mu \mathrm{m}) / \mathrm{LSM}-$ 
YSZ layer. First, the anode substrate of nickel oxide (Aldrich, 325 mesh) and YSZ (Tosoh, TZ-8Y) with a weight ratio of 60 to 40 was mixed by ball milling for 24 hrs and pressed into a disk with $\sim 1 \mathrm{~mm}$ thickness. The slurry of YSZ was obtained by mixing YSZ powder with organic solutions, binders, and plastics for $20 \mathrm{hrs}$. After that the YSZ slurry was coated onto the pre-calcined anode substrate, the halfcell with the anode substrate and the thin YSZ electrolyte was sintered at $1350{ }^{\circ} \mathrm{C}$ for $5 \mathrm{hrs}$. The thickness of the YSZ electrolyte can be controlled by the slurry concentration, and in the present study, it was 5-10 $\mu \mathrm{m}$. A cathode of either $\left(\mathrm{La}_{0.8} \mathrm{Sr}_{0.2}\right)_{0.95} \mathrm{MnO}_{3-\delta}(\mathrm{LSM})-\mathrm{YSZ}$ was screen printed on the surface of the YSZ electrolyte, by calcining at $1100{ }^{\circ} \mathrm{C}$ for $2 \mathrm{hrs}$. The cathode area of the anode-supported cell was the same as the cathode for the electrolyte-supported cell. Finally, the as-prepared cell in $\sim 20 \mathrm{~mm}$ diameter was painted with silver paste, pre-calcined at $800{ }^{\circ} \mathrm{C}$ for $1 \mathrm{hr}$, on both sides of the anode and the cathode.

Either an electrolyte-supported cell or an anode-supported cell was sealed on the alumina tube using sealant (Aremco 552), with the anode side up. $2 \mathrm{~g}$ mixture of carbon-carbonate (4:1) was weighed and filled into the anode chamber. The purge gas of $\mathrm{N}_{2}$ was controlled by the valves, and the flow rate of gas was $20 \mathrm{ml} / \mathrm{min}$. The cell performance was measured on Solartron $1280 \mathrm{~B}$ with $10 \mathrm{mV}$ ac disturbed for $\mathrm{AC}$ impedance and $20 \mathrm{mV} / \mathrm{step}$ to scan current-voltage curves.

\subsection{Sample analysis}

The gas analysis was performed on a 3000 micro-Gas Chromatograph equipped with two capillary columns and a backflush injector. A $320 \mu \mathrm{m} \times 10 \mathrm{~m}$ MolSieve column with argon as the carrier gas, was used for hydrogen, nitrogen, carbon monoxide, and methane detection. A $320 \mu \mathrm{m} \times 8 \mathrm{~m}$ PlotU column equipped with a helium carrier gas for carbon dioxide detection. Injection occurred through a backflush injector operated at $110^{\circ} \mathrm{C}$. The separation occurred at $100^{\circ} \mathrm{C}$ and $60^{\circ} \mathrm{C}$ with a pressure of $30 \mathrm{psi}$ a for MolSieve column and Plot column, respectively. In long-term tests the percentages of gas output were determined, these were converted to gas volumes using the nitrogen purge gas as an internal standard. As the gas content is slightly overestimated the amount of carbon produced over long-term tests, these were then normalised against the total amount of carbon utilised.

The X-ray diffraction (XRD) patterns of carbon samples were recorded on a PANalytical Empyrean Reflection Diffractometer with Cu Ka radiation $(\lambda=1.5418 \AA)$ using settings of $40 \mathrm{~mA}$ and $40 \mathrm{kV}, 2 \theta$ range of $10-90^{\circ}$, step size of $0.02^{\circ}$ and scan step time of $2 \mathrm{~s}$. A Fourier Transform Infrared spectrophotometer (FTIR; Shimadzu, IRAffinity-1S) was used for the FTIR spectra measurements. The 
elements of carbon, hydrogen, nitrogen, and sulfur in GC, CB, or BC was analysed with CHNS element analysis (EA 1110 CHNS). The carbon powders were tested on Scanning Electron Microscope Jeol JSM-5600.

\section{Rusults}

\subsection{Electrochemical performance of electrolyte-supported cells}

The electrochemical reactivity of different carbon fuels was evaluated on HDCFC with a thin $\mathrm{NiO}$ anode. Fig.1 shows electrochemical performance of HDCFCs with GC, CB, and BC fuels. The polarisation curves of these three carbon fuels are similar in shape with linear curves presented. It demonstrates that BC produced the highest cell performance (Fig. 1a). GC-fuelled cell gave slightly lower performance than the BC-fuelled cell. The HDCFC operated with $\mathrm{CB}$ fuel offered the lowest performance. The maximum power density for GC fuelled HDCFC and BC fed HDCFC is $49 \mathrm{~mW} \mathrm{~cm}{ }^{-2}$ and $52 \mathrm{~mW} \mathrm{~cm}^{-2}$, respectively, while the maximum power density of HDCFC with CB fuel is only $25 \mathrm{~mW} \mathrm{~cm}^{-2}$. Although $\mathrm{BC}$ and GC generate similar initial cell performance, these two fuels seem to differ regarding cell durability. Fig. 1b, which shows the current density recorded under a constant load for each fuel, indeed indicates that the cell using GC shows the best stability. The AC impedance spectra in Fig. 1c confirm these results, smaller resistance obtained on the HDCFC with BC and GC fuels, but larger resistance value when carbon black as the fuel.

The open circuit voltages of the cells with three different carbon fuels are slightly different. CB presents the low OCV value, which is $1.09 \mathrm{~V}$, and the other two carbon fuels give somewhat higher voltages of $1.13 \mathrm{~V}$ and $1.15 \mathrm{~V}$ for $\mathrm{GC}$ and $\mathrm{BC}$, respectively. 

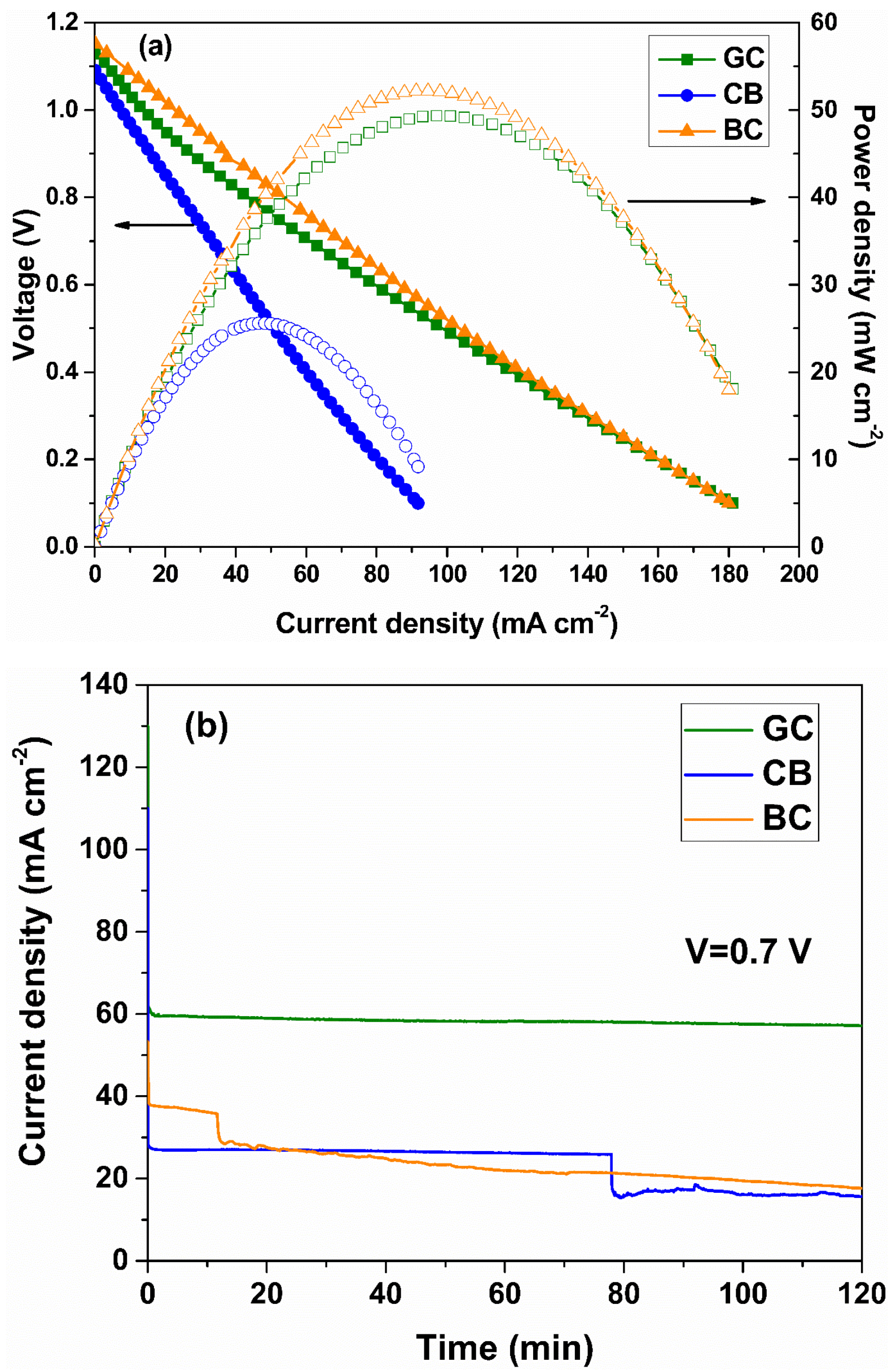


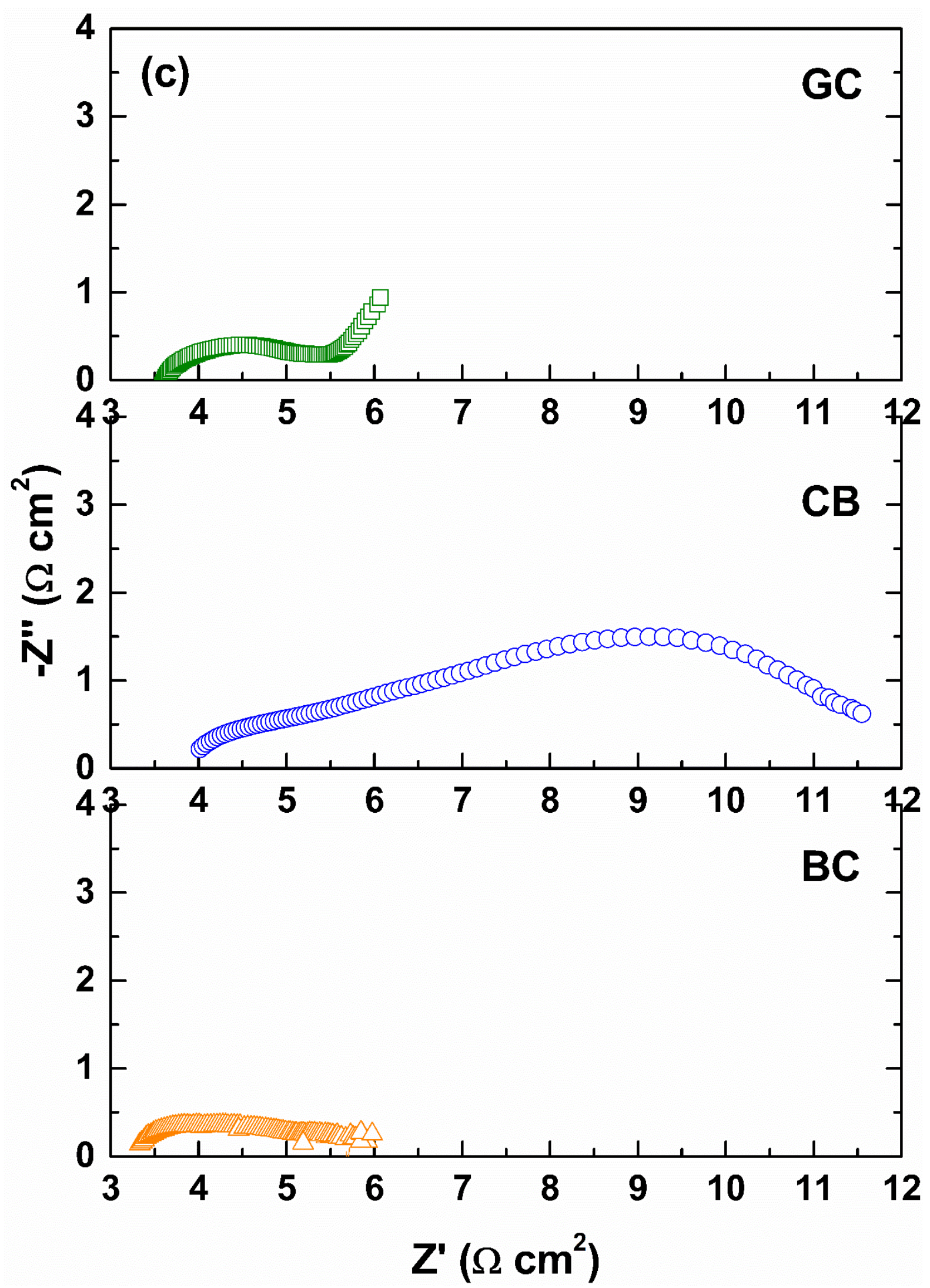

Fig. 1 Electrochemical performance of the electrolyte-supported HDCFCs with GC, CB or BC as the fuel. (a) I-V-P curves; (b) Durability of the cell under $0.7 \mathrm{~V}$ potential; (c) Ac impedance spectra. 


\subsection{Properties of fuels}

To evaluate the possible dominant impact on the HDCFC performance, fuels used in this article are characterised on crystal structure, particle size, impurities and surface properties of the fuels.

\section{Crystallinity}

The DCFC performance may be dominated by structure, such as the graphitisation or surface properties. Amorphous carbon, such as active carbon, was reported easier to convert electrochemically due to the many types of reaction site (an edge, step, or other surface imperfection) for carbon oxidation [20]. Nurnberger [30] and Kulkarni [31] reported that amorphous carbon black was more reactive than graphitic carbon in DCFCs, which utilised a solid oxide electrolyte. Nurnberger et al.[30] developed a direct contact method to convert the chemical energy of Vulcan XC72R and GC (GFG 50M) into electricity. Their results show that Vulcan XC72R fuel generates a better performance compared to the cell with GC. The higher activity of amorphous carbon has been reported as well for molten carbonate electrolytes [20].

Carbon fuels with a typical crystal structure are chosen for investigation. CB and BC belong to amorphous carbon, but the former is pure carbon, the latter has impurities except for carbon. Fig. 2 shows the XRD patterns of GC, CB, and BC. It can be observed that an intense peak of $26.5^{\circ}$ is the (002) graphitic basal plane reflection. Both of $C B$ and $B C$ have a broad diffraction peak at $23.44^{\circ}$, which is also (002) reflection. Another broad peak at $43.05^{\circ}$ is the (001) GC crystal faces reflection in each pattern of carbon black and BC. These diffraction patterns confirm that carbon black and BC have amorphous structures while GC is ordered. 

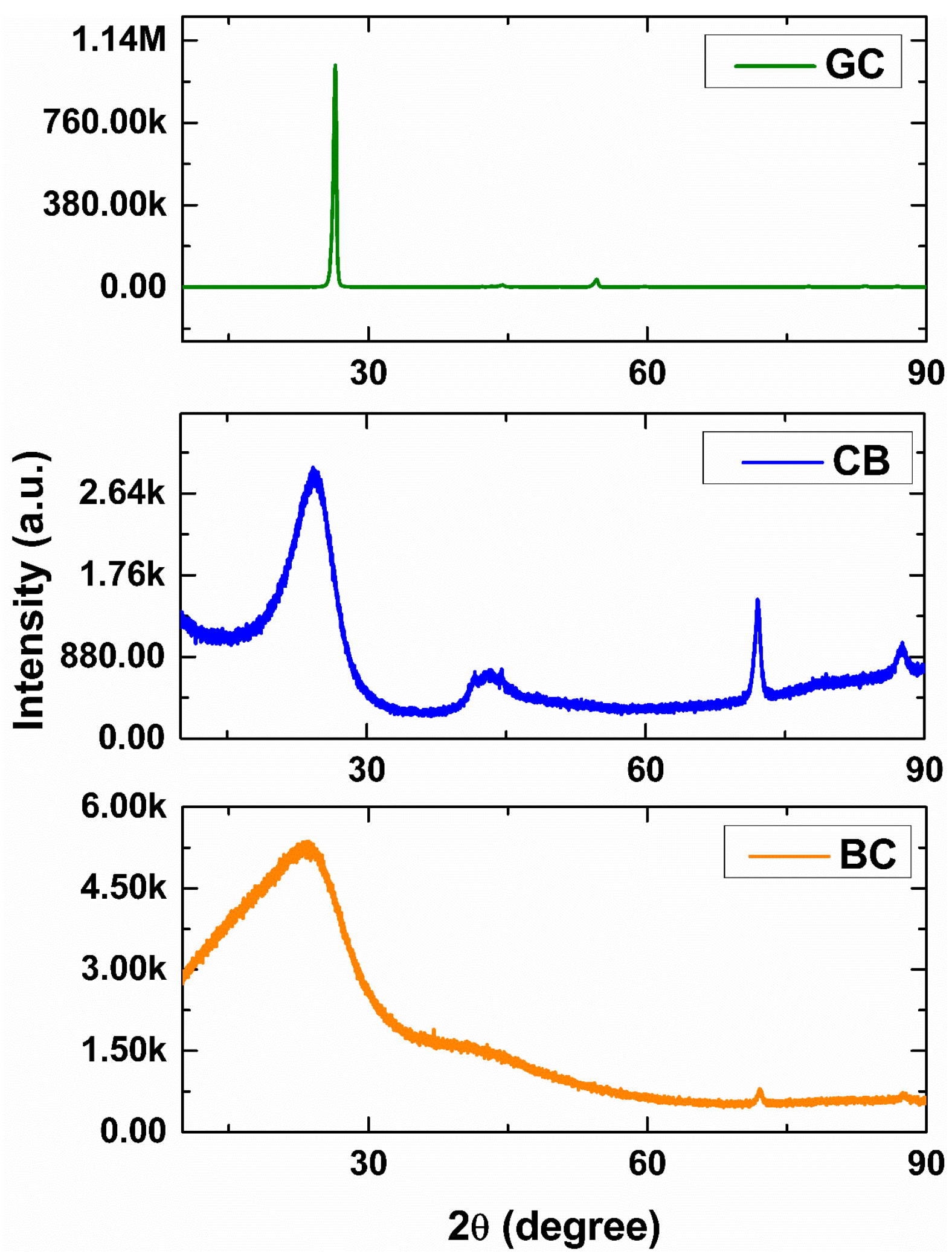

Fig. 2 XRD patterns of GC, CB and BC

\section{Particle size}

The primary particle size of the solid carbon is one parameter determining DCFC performance. In Vutetakis initial experiment, the current density of the cell increased as the particle size of coal 
decreased in molten carbonate slurry under $100 \% \mathrm{CO}_{2}$ gas at $700{ }^{\circ} \mathrm{C}[24$ ]. Lee et al. [32] also found a similar trend in SOFC mode for direct carbon oxidation. They found there is an influence of the GC particle size on the open-circuit voltage of tubular cells. It showed that the direct carbon fuel cell with the smallest particles size $(32 \mu \mathrm{m})$ coal exhibited the highest open-circuit voltage (OCV) in the temperature range from $200^{\circ} \mathrm{C}$ to $1000^{\circ} \mathrm{C}$. We had found the similar results of the influence of particle size on the OCV. CB has the smallest particle size and therefore gave the highest OCV value of 1.15 $\mathrm{V}$ (Fig. 1a), while BC has the biggest particle size among there carbon fuels so that the lowest OCV value of $1.09 \mathrm{~V}$ (Fig. 1a) was obtained. The higher OCV could be explained by the increased number of available active sites implying a higher chemical activity of the fuel.

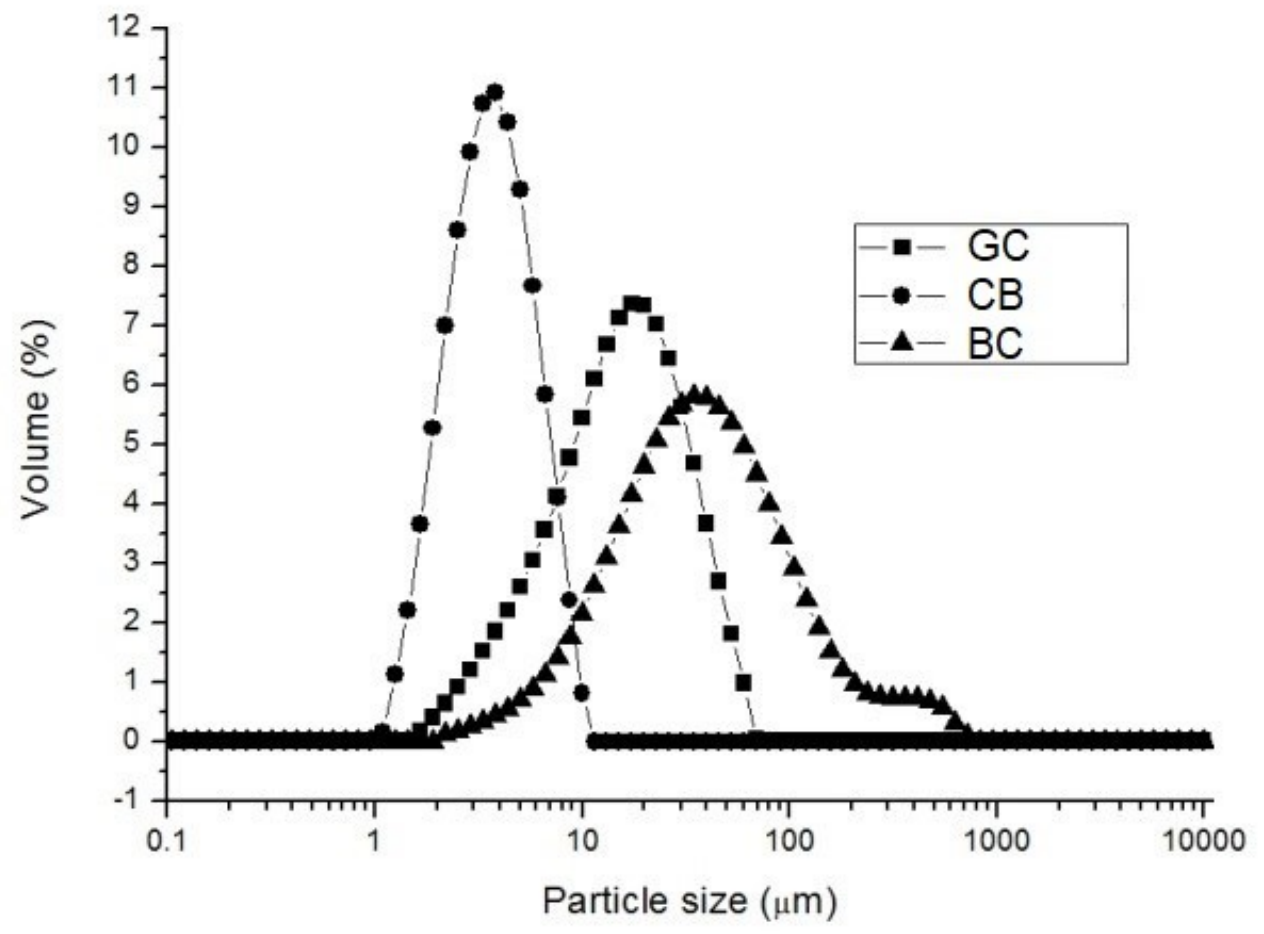

Fig. 3 Particle size and distribution of GC, CB and BC

Fig. 3 and Fig. 4 show the particle size of tested carbon fuels and SEM picture of each carbon, respectively. CB has the smallest particle size and also, of course, a large surface area $\left(250 \mathrm{~m}^{3} / \mathrm{g}\right)$. The particle size of $\mathrm{BC}$ is big, and it also can be seen from Fig. 3 that the particle size distribution has two ranges, and some big particles exist in the range of 200 um to $1000 \mu \mathrm{m}$. GC's particle size is not big, and the average size is $20 \mu \mathrm{m}$. The result shows that carbon with a small surface area performs better than carbon with a large surface area, which could be explained by the low reacting ability of low surface 
area carbon. And also, part of the fuel will be lost by the gasification process instead of being oxidised electrochemically, therefore lower utilisation will be obtained.
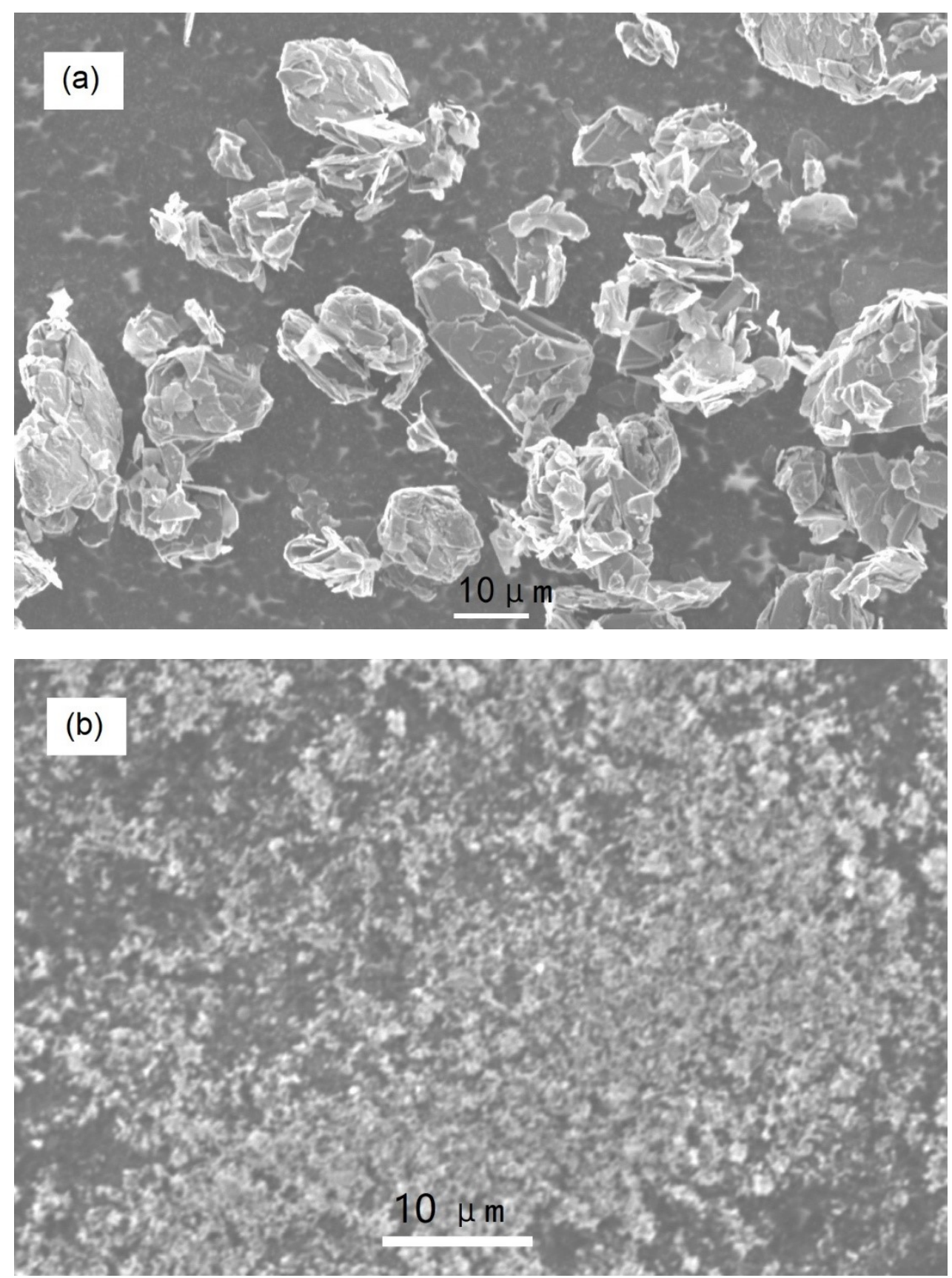


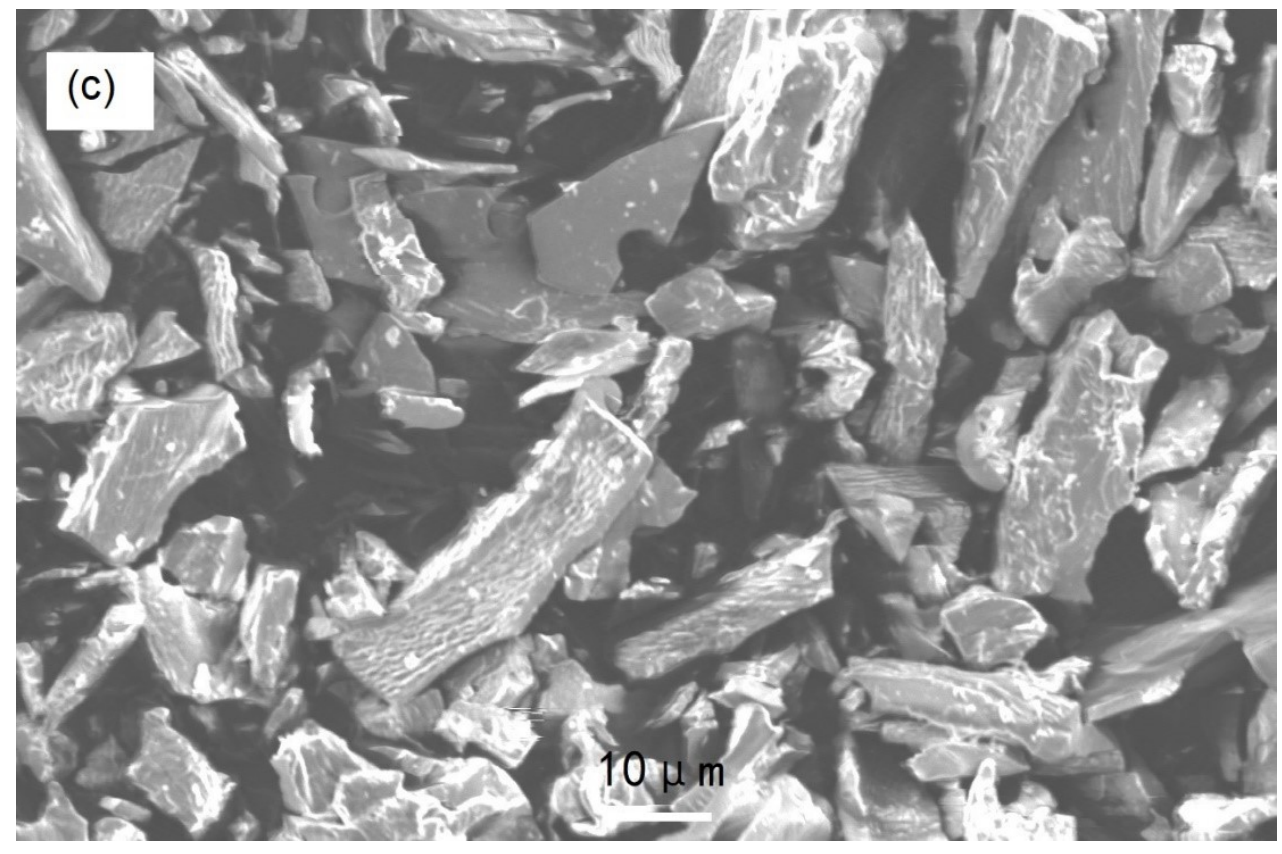

Fig. 4 SEM images of $\mathrm{GC}, \mathrm{CB}$ and $\mathrm{BC}$ fuel

\section{Composition}

In some carbon fuels such as biomass-derived chars and coals, species containing hydrogen, oxygen, nitrogen, and sulfur may also be involved in the electrochemical process. Coal and biomass carbons contain variable amounts of non-carbon species such as tars [33]. These species might be able to improve cell performance as well as more natural activation. In impure carbon, the high-temperature pyrolysis products such as hydrogen and methane can be oxidised and so that electricity is generated. Sulfur in coal is harmful to the cell power output if nickel is used for the catalyst because it is sensitive to the presence of sulfur.

GC and $\mathrm{CB}$ are commercial samples. Among them, GC has high purity with $0.01 \%$ nitrogen. There are $0.09 \%$ nitrogen in $\mathrm{CB}$, and some oxygen presents as well, while $\mathrm{BC}$ has a much lower carbon content, which is only $70.4 \%$. The other elements like hydrogen, nitrogen is $3.5 \%$ and $4.6 \%$ respectively. There is a significant amount of oxygen $(21.5 \%)$ in BC. The high oxygen level provides a benefit to the cell initial performance as we can see $\mathrm{BC}$ generated the best initial performance among all three-carbon fuels. This result is in good agreement with the result that pre-oxidised coal with much high oxygen contents generated higher initial power density in the same conditions in other publication [34]. CB and $\mathrm{BC}$ used in this research have chemisorbed oxygen complexes (i.e., carboxylic, quinonic, lactonic, phenolic groups and other) as we can see from their high oxygen content (Table 1). These surface oxygen groups are often referred to as volatile content. The volatile matter plays an essential role in cell 
performance. However, the volatile matter decomposes as a loss, and only part of the decomposition takes part in the chemical reactions before the cell is on the operation (cell's target temperature is $750{ }^{\circ} \mathrm{C}$ in here). There are $30 \mathrm{wt} \%$ loss from $\mathrm{BC}$ tested in nitrogen, while only a little loss from GC shown in TG results in our previous paper [27].

There are some other elements in BC (hydrogen, nitrogen). When using BC as fuel, the amount of each gas (hydrogen, nitrogen) from the outlet of the anode is much more than the amount of the corresponding gas in $\mathrm{CB}$ fuel and GC (Table 1). For coal, there are some impurities, such as $\mathrm{Al}_{2} \mathrm{O}_{3}$, $\mathrm{SiO}_{2}, \mathrm{CaO}, \mathrm{MgO}$, and $\mathrm{Fe}_{2} \mathrm{O}_{3}$. Contaminants such as $\mathrm{Al}_{2} \mathrm{O}_{3}$ and $\mathrm{SiO}_{2}$ lead to an inhibitive effect during the anodic reaction in the DCFC, while $\mathrm{CaO}, \mathrm{MgO}$ and $\mathrm{Fe}_{2} \mathrm{O}_{3}$ exhibit a catalytic effect on the electrochemical oxidation of carbon[17]. There are no impurities in GC, $C B$, and $B C$, so that no inorganic impurities issue is involved in this study. Detailed research of the contaminants on the GC oxidation can be found in Tulloch's report [35].

Table 1 Element analysis of GC, CB, and BC

\begin{tabular}{cccccc}
\hline Element & $\mathrm{C}$ & $\mathrm{H}$ & $\mathrm{N}$ & $\mathrm{S}$ & $\mathrm{O}$ \\
\hline $\mathrm{GC}$ & 99.9 & 0.00 & 0.01 & 0.00 & 0.00 \\
$\mathrm{CB}$ & 97.02 & 0.00 & 0.09 & 0.00 & 2.89 \\
$\mathrm{BC}$ & 70.4 & 3.50 & 4.60 & 0.00 & 21.5 \\
\hline
\end{tabular}

\section{Surface properties}

Fig. 5 shows the FTIR spectra of each carbon fuel. We can see from the FTIR spectra, aromatic peaks and conjugates and non-conjugates bonds are clearly visible at 1690 and $1606 \mathrm{~cm}^{-1}$ for $\mathrm{BC}$, while the same peaks are partially visible or absent for CB and GC. The same heights were observed by FTIR analysis, which has been found in Solum's research. The peak at $1383 \mathrm{~cm}^{-1}$ is the only peak visible in all of three spectra because they characterise the methyl group as a terminal in the aromatic cluster and the intensity of these peaks can be used to determine the amount of aromatic cluster in the structure. And also, comparing three different types of carbons (GC, CB, and $B C$ ) by FTIR analysis, we can observe how the aromatic bonds and $\mathrm{C}-\mathrm{O}$ peaks decrease as a function of the extent of carbon oxidation. 




Fig. 5 FTIR spectra of GC, CB and BC

\subsection{Gas products}

The TPD files of DCFCs under open-circuit voltage condition using these three carbons are shown in

Fig. 6. Although it is difficult to directly retrieve information about the exact type of surface functional 
group, the general information on reactive surface sites can be derived from the TPD profiles. Four gases of $\mathrm{H}_{2}, \mathrm{CO}, \mathrm{CO}_{2}$, and $\mathrm{CH}_{4}$ were observed. During the TPD process, the surface complexes would release $\mathrm{CO}_{2}$ and $\mathrm{CO}$ at different temperatures. In general, $\mathrm{CO}_{2}$ evolves from the decomposition of carboxylic acid functionality at low temperatures and/or lactones at high temperatures, while CO arises from the phenols and carbonyls at high temperature.[36] As expected, GC produces the smallest amounts of all gases, like $\mathrm{H}_{2}, \mathrm{CO}, \mathrm{CO}_{2}$, and $\mathrm{CH}_{4}$ due to the greatest extent of carbon oxidation. It can be seen that there is no hydrogen ( $0 \%$ hydrogen from element analysis in Table 1$)$, while more hydrogen product in the BC (3.53\% hydrogen from element analysis in Table 1) fuelled cell since there are more $-\mathrm{OH}$ stretch and $\mathrm{C}-\mathrm{H}$ aliphatic functional groups in $\mathrm{BC} . \mathrm{CO}_{2}$ and $\mathrm{CO}$ evolution from $\mathrm{GC}$ is nearly negligible, indicating a surface clean of oxygen complex groups, whereas BC generates the most significant amount of $\mathrm{CO}_{2}$ with a maximum peak at around $450{ }^{\circ} \mathrm{C}$. This result can be confirmed by the low oxygen content in GC, as shown in Table 1(no oxygen in GC). CO evolution takes place at a much higher temperature, and the height of $\mathrm{CO}$ evolution for $\mathrm{BC}$ and $\mathrm{CB}$ are located at $675^{\circ} \mathrm{C}$ and $750{ }^{\circ} \mathrm{C}$ [37]. In addition, little methane is found between 400 to $500{ }^{\circ} \mathrm{C}$ from the off-gas, which is produced by the pyrolysis process of the carbon when $\mathrm{CB}$ and $\mathrm{BC}$ as the fuel, while no methane is observed with GC as the fuel (Fig. 6). With the temperature increasing methane reacts with water and produces hydrogen and carbon dioxide by eqn. (1).

$$
\mathrm{CH}_{4}+\mathrm{H}_{2} \mathrm{O} \rightarrow 3 \mathrm{H}_{2}+\mathrm{CO}
$$

Methane is completely consumed to produce hydrogen and carbon monoxide higher than the testing temperature of $750^{\circ} \mathrm{C}$. Carbon has a different crystal structure, and the oxidation of carbon into carbon dioxide is determined by the activation of the carbon itself. For the semi-pyrolysed carbon, it is easier to be activated since more active species or bonds to carbon and therefore much better cell performance. This product of hydrogen is helpful with the reduction of nickel oxide to nickel metal. The evolution profile of these four different gases is more likely related to the nickel reduction as there is no electrochemical reactions happens. Therefore, the cell performance with different GC is more related to the cell itself rather than the pyrolysis gases. The initial cell performance was governed primarily by the amount of hydrogen and $\mathrm{CO}$ released at $750{ }^{\circ} \mathrm{C}$ (as the cell performance is tested at this temperature). It must be noticed that water produced by hydrogen electrooxidation can react with carbon and generate active gases, like hydrogen and CO. Further research is necessary to evaluate the influence of this reaction on the cell performance. 

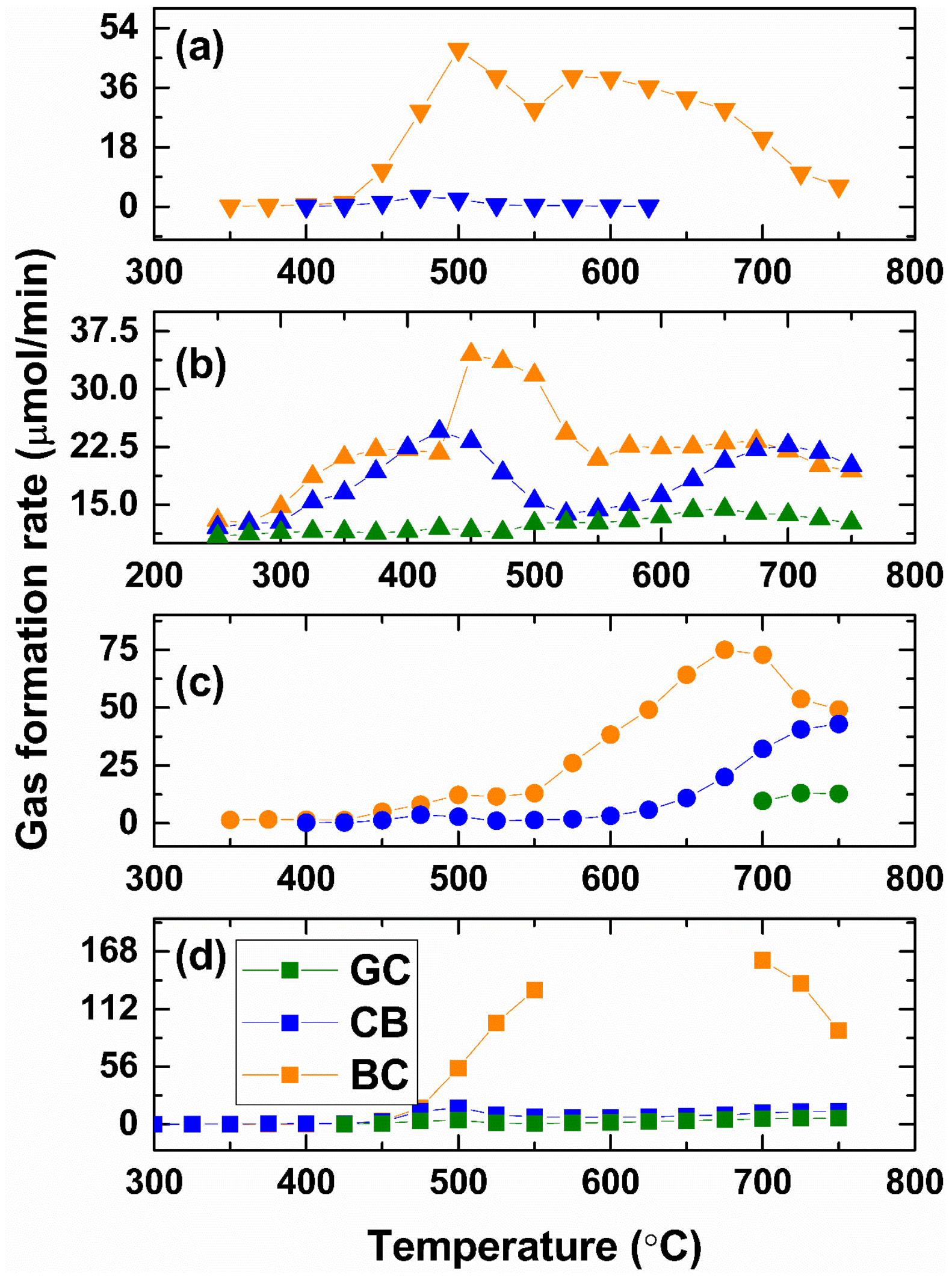

Fig. 6 Gas products of the outlet for the cells with $\mathrm{GC}, \mathrm{CB}$ or $\mathrm{BC}$ as the fuel (Formation rate of hydrogen from $\mathrm{BC}$ fuel at $550{ }^{\circ} \mathrm{C}$ to $700{ }^{\circ} \mathrm{C}$ is above the limitation of $\mathrm{GC}$ detect). (a) $\mathrm{CH}_{4}$; (b) $\mathrm{CO}_{2}$; (c) $\mathrm{CO} ;(\mathrm{d}) \mathrm{H}_{2}$ 
Fig. 7 shows the gas analysis under current load (cell performance shown in Fig. 1b). It can be seen that that similar amounts of $\mathrm{CO}_{2}$ are produced for these three carbons, while there are significant differences for $\mathrm{CO}$ and $\mathrm{H}_{2}$ products. In the beginning, hydrogen oxidation is the dominant process, along with carbon oxidation. With the time increase, less hydrogen left in the anode chamber as the diffusion rate of hydrogen is fast. A much lower $\mathrm{CO}$ formation rate for $\mathrm{GC}$ than $\mathrm{CB}$ and $\mathrm{BC}$ was found in the first 30 mins. After 30 mins of the durability test, a significant amount $\mathrm{CO}$ is produced when GC is used for the fuel, which might be because the cell performance is dominant by carbon oxidation and Boudouard reaction in the process.[37] The CO formation was due to the slow oxidation rate of GC because of its high extent of graphitisation (Fig. 2). CB and BC are amorphous and more active than GC. which has been displayed in TGA tests in our previous paper, in where the onset of oxidation temperature is around $640{ }^{\circ} \mathrm{C}$ while that is about $540{ }^{\circ} \mathrm{C}$ [27]. As compared to the electrochemical reaction rate of hydrogen, carbon oxidation is a slow process. Therefore, after a certain time, carbon oxidation is the dominant process. GC has the highest amount of carbon, which might be the reason that GC-fuelled direct carbon fuel cell gives better cell performance than other carbons-fuelled cells (Fig. 1a). 


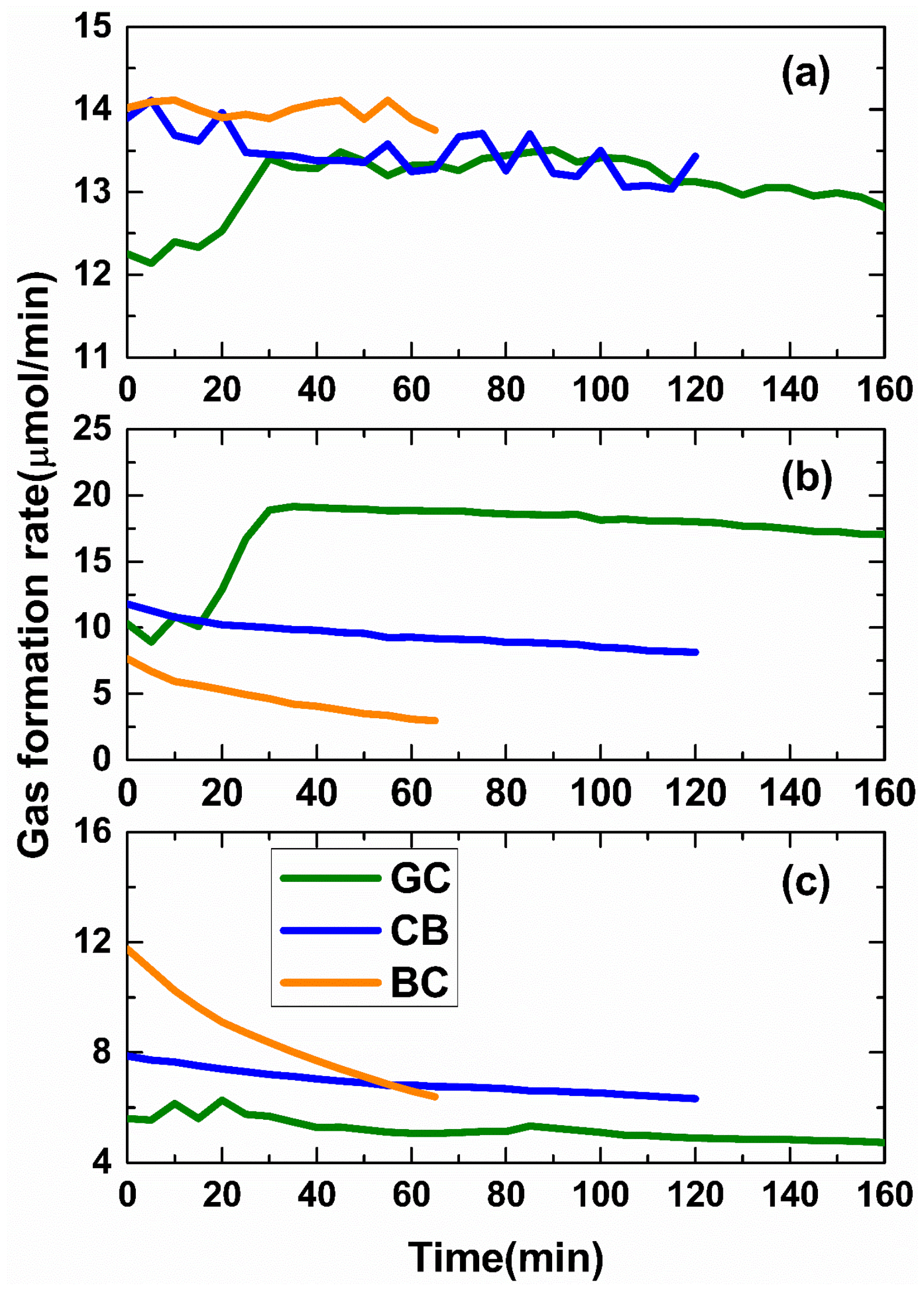

Fig. 7 Gas analysis of the HDCFC operating at $0.7 \mathrm{~V}$ using $\mathrm{GC}, \mathrm{CB}$ or $\mathrm{BC}$ as the fuel. (a) $\mathrm{CO}_{2}$; (b)CO;

(c) $\mathrm{H}_{2}$ 


\subsection{HDCFC performance on a thick NiO anode}

HDCFC performance was investigated on thick $\mathrm{NiO}$ anodes using these three carbon fuels. The open-circuit voltage was recorded when the HDCFC was heating up to the operating temperature of $750^{\circ} \mathrm{C}$. The cell OCV increases with the increase in temperature using $\mathrm{CB}$ and GC fuels. $\mathrm{NiO}$ is reduced when the temperature is higher than $500^{\circ} \mathrm{C}$. It can be seen from Fig. $8 \mathrm{a}, \mathrm{CB}$ fuelled HDCFC is reduced so fast, while it takes a much longer time for GC fuelled HDCFC to be reduced. It is not even fully reduced when the cell reached to the test temperature of $750^{\circ} \mathrm{C}$, and the $\mathrm{OCV}$ is only $0.75 \mathrm{~V}$. The initial cell performance of the GC-fuelled DCFC is much lower than the CB-fuelled DCFC (Fig. 8b). The cell is reduced when it is operating at $750{ }^{\circ} \mathrm{C}$ for 10 hours, and the cell performance is improving with time (Fig. 8c).

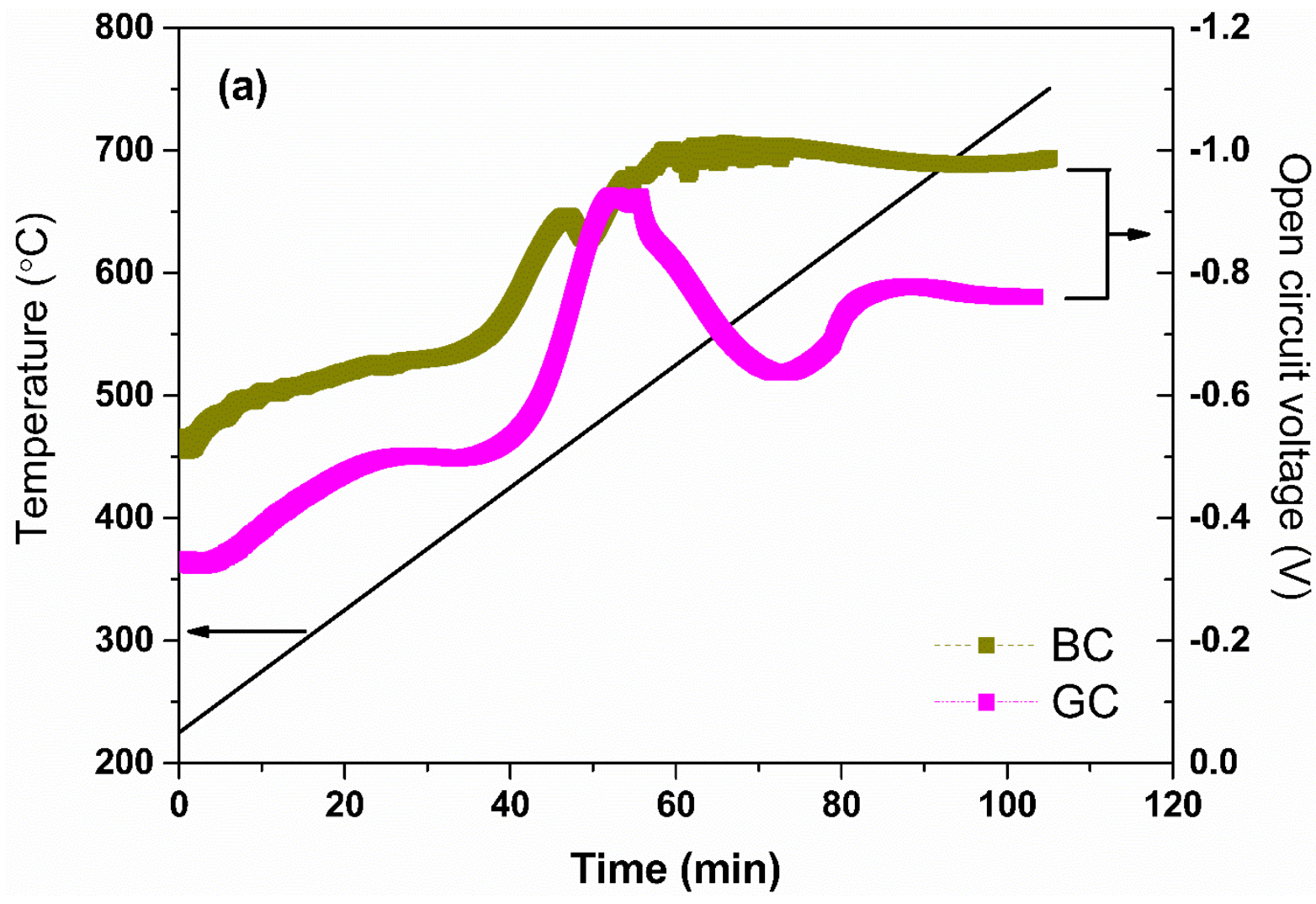




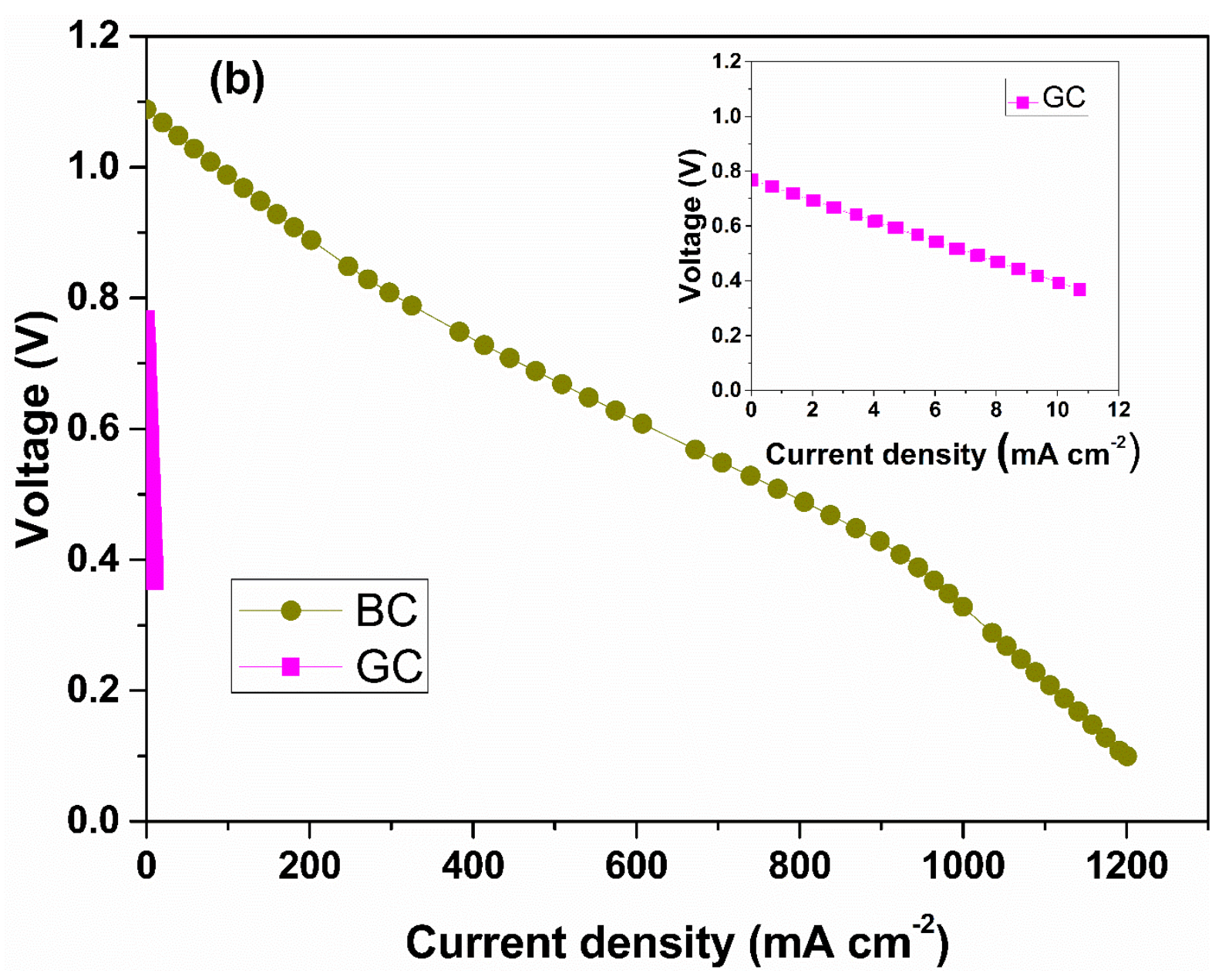




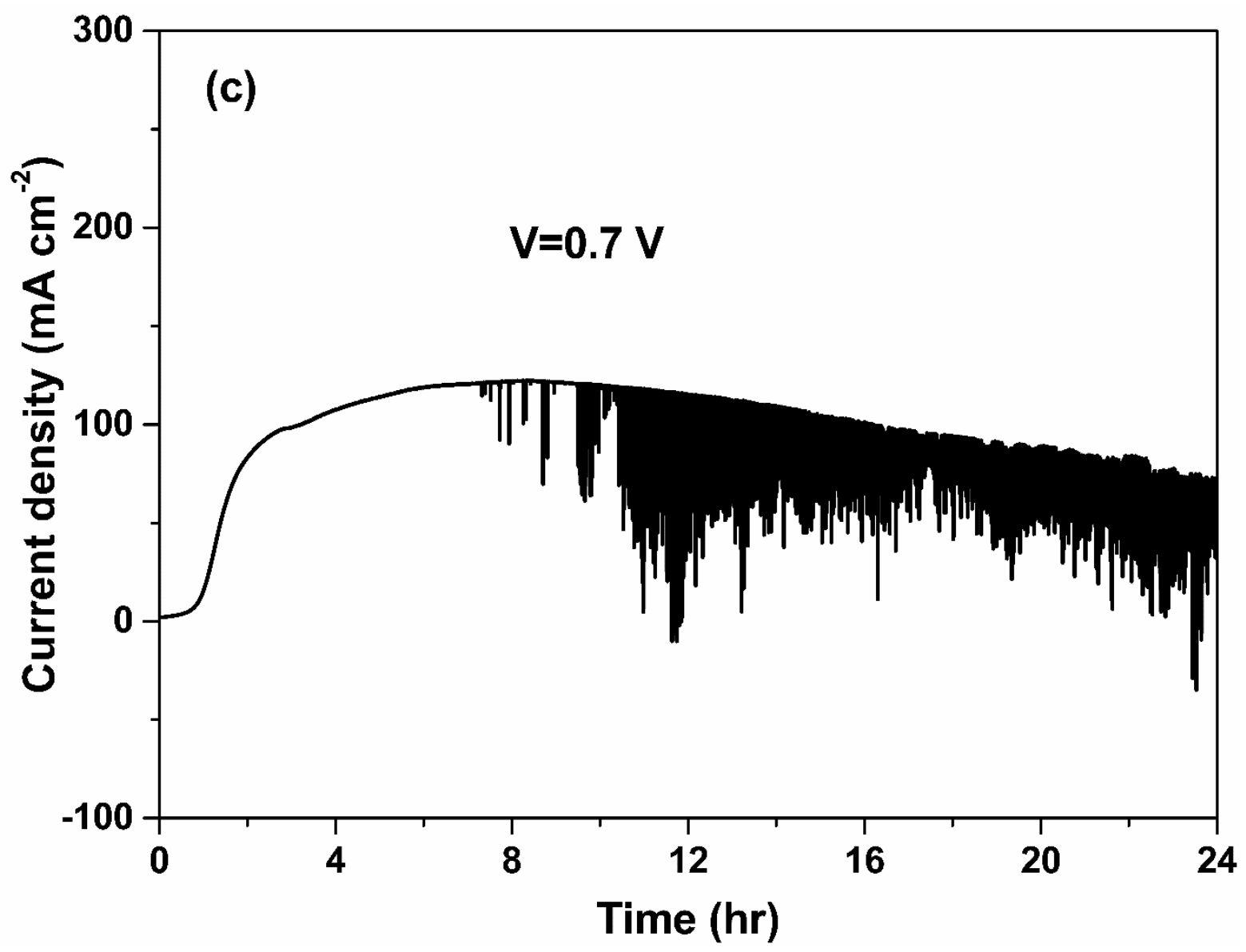

Fig. 8 Electrochemical performance of a NiO-anode supported cell with a configuration of $1 \mathrm{~mm}$ thick $\mathrm{NiO}$ anode/ thin $\mathrm{YSZ}$ elekctrolyte/(La0.8 $\left.\mathrm{Sr}_{0.2}\right)_{0.95} \mathrm{MnO}_{3-\delta} / \mathrm{YSZ}$ composite cathode, using GC or $\mathrm{BC}$ as a fuel. (a) Open circuit voltage of HDCFC with time during the cell is heating up to $750^{\circ} \mathrm{C}$; (b) I-V curves of HDCFC operating at $750^{\circ} \mathrm{C}$ with $\mathrm{GC}$ or $\mathrm{CB}$ as the fuel; (c) Long-term stability of HDCFC tested at $750^{\circ} \mathrm{C}$ with $\mathrm{GC}$ as the fuel

Fig. 9 displays the formation rate of carbon monoxide at different voltage loads tested at $750{ }^{\circ} \mathrm{C}$. It can be seen that the $\mathrm{CO}$ formation rate decreases with the voltage load. The high $\mathrm{CO}$ content shows that it is desirable of partially carbon oxidation at high current (low voltage) with more products of CO. 


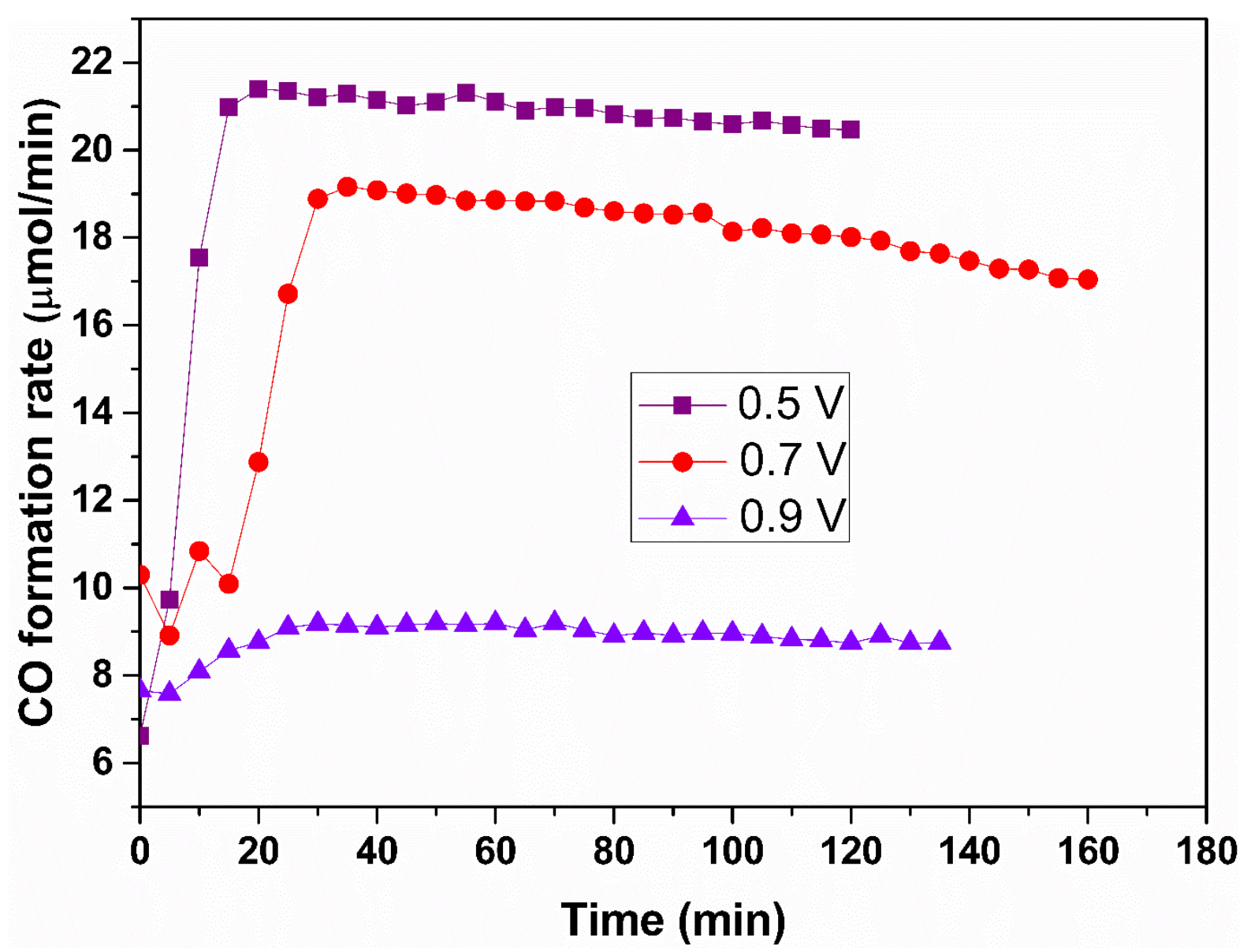

Fig. $9 \mathrm{CO}$ formation of the HDCFC with a configuration of $1 \mathrm{~mm}$ thick $\mathrm{NiO}$ anode/ thin $\mathrm{YSZ}$ elekctrolyte/(La0.8 $\left.\mathrm{Sr}_{0.2}\right)_{0.95} \mathrm{MnO}_{3-\delta} / \mathrm{YSZ}$ composite cathode, operating at different voltage loads with GC as the fuel

\section{Conclusion}

The electrochemical reactivity of carbon fuels on nickel oxide-based hybrid direct carbon fuel cells (HDCFCs) is investigated. Graphite (GC), carbon black (CB), and biomass carbon (BC) fuels were chosen as the fuel. GC generated good initial cell performance and long-term stability on the electrolytesupported HDCFC. It suggested that the HDCFC performance is affected by composition and surface property, and is less likely to be dependent on the particle size and the crystal structure when using thin nickel oxide anode. However, GC showed the worst cell performance and reasonable durability on the anode-supported cell, indicating that the reactivity of carbon on anode-supported is possibly related to the crystal structure, composition, and surface property. TPD files of the HDCFCs show that $\mathrm{H}_{2}$ and CO are the two main gases. In-situ gas analysis under voltage load showed that hydrogen oxidation contributed partially to the cell performance, and however after a certain time when the hydrogen is not the dominant composition, carbon oxidation is the dominant process with $\mathrm{CO}$ released probably 
because of the Boudourad reaction. This study demonstrates attractive attributes of the mechanism insight of carbon oxidation by in-situ gas analysis, suggesting that GC is a potential fuel for hybrid direct carbon fuel cells.

\section{Acknowledgement}

This work was supported by Sichuan Science and Technology Program (grant number 2019YFH0177); the talent introduction plan of Sichuan University of Science and Engineering (grant numbers 2016RCL36, 2016RCL37); enterprise cooperation project (grant number HX2017087); and the opening project of Material Corrosion and Protection Key Laboratory of Sichuan Province (grant numbers 2017CL11 and 2017CL13). CJ acknowledges the Royal Society of Edinburgh for an RSE BP Hutton Prize in Energy Innovation.

\section{References}

[1]Wu W, Zhang Y Y, Ding D, He T. A High-Performing Direct Carbon Fuel Cell with a 3D Architectured Anode Operated Below 600 degrees C. Adv Mater 2018; 30: 6.

[2]Rady A C, Giddey S, Kulkarni A, Badwal S P S, Bhattacharya S, Ladewig B P. Direct carbon fuel cell operation on brown coal. Appl Energ 2014; 120: 56-64.

[3]Jiang C, Ma J, Corre G, Jain S L, Irvine J T S. Challenges in developing direct carbon fuel cells. Chem Soc Rev 2017; 46: 2889-912.

[4]Zhang J B, Zhong Z P, Zhao J X, Yang M, Li W L, Zhang H Y. Study on the preparation of activated carbon for direct carbon fuel cell with oak sawdust. Can J Chem Eng 2012; 90: 762-8.

[5]Nabae Y, Pointon K D, Irvine J T S. Ni/C Slurries Based on Molten Carbonates as a Fuel for Hybrid Direct Carbon Fuel Cells. J Electrochem Soc 2009; 156: B716-B20.

[6]Li X, Zhu Z H, Chen J L, De Marco R, Dicks A, Bradley J, et al. Surface modification of carbon fuels for direct carbon fuel cells. J Power Sources 2009; 186: 1-9.

[7]Jain S L, Nabae Y, Lakeman B J, Pointon K D, Irvine J T S. Solid state electrochemistry of direct carbon/air fuel cells. Solid State lonics 2008; 179: 1417-21.

[8]Liu R Z, Zhao C H, Li J L, Zeng F R, Wang S R, Wen T L, et al. A novel direct carbon fuel cell by approach of tubular solid oxide fuel cells. J Power Sources 2010; 195: 480-2.

[9]Guo L, Calo J M, Dicocco E, Bain E J. Development of a Low Temperature, Molten Hydroxide Direct Carbon Fuel Cell. Energ Fuel 2013; 27: 1712-9. 
[10]Lee E K, Park S A, Jung H W, Kim Y T. Performance enhancement of molten carbonate-based direct carbon fuel cell (MC-DCFC) via adding mixed ionic-electronic conductors into $\mathrm{Ni}$ anode catalyst layer. J Power Sources 2018; 386: 28-33.

[11]Fini D, Badwal S P S, Giddey S, Kulkarni A P, Bhattacharya S. Evaluation of $\mathrm{Sc}_{2} \mathrm{O}_{3}-\mathrm{CeO}_{2}-\mathrm{ZrO}_{2}$ electrolyte-based tubular fuel cells using activated charcoal and hydrogen fuels. Electrochim Acta 2018; 259: $143-50$.

[12]Hackett G A, Zondlo J W, Svensson R. Evaluation of carbon materials for use in a direct carbon fuel cell. J Power Sources 2007; 168: 111-8.

[13]Weaver R D, Leach S C, Bayce A E, Nanis L. Direct Electrochemical Generation of Electricity from Coal. Quarterly progress report No. 2 (Monthly progress report No. 6). United States: N. p., 1976. Web. [14]Ahn S Y, Eom S Y, Rhie Y H, Sung Y M, Moon C E, Choi G M, et al. Application of refuse fuels in a direct carbon fuel cell system. Energy 2013; 51: 447-56.

[15]Chen C-C, Maruyama T, Hsieh P-H, Selman J R. The Reverse Boudouard Reaction in Direct Carbon Fuel Cells. Ecs Transactions 2010; 28: 227-39.

[16]Peng F, Li Y, Nash P, Cooper J F, Parulekar S J, Selman J R. Direct Carbon Fuel Cells - Wetting behavior of graphitic carbon in molten carbonate. Int J Hydrogen Energy 2016; 41: 18858-71.

[17]Li X, Zhu Z H, De Marco R, Bradley J, Dicks A. Evaluation of raw coals as fuels for direct carbon fuel cells. J Power Sources 2010; 195: 4051-8.

[18]Li X, Zhu Z H, De Marco R, Dicks A, Bradley J, Liu S M, et al. Factors That Determine the Performance of Carbon Fuels in the Direct Carbon Fuel Cell. Industrial \& Engineering Chemistry Research 2008; 47: 9670-7.

[19]Ahn S Y, Eom S Y, Rhie Y H, Sung Y M, Moon C E, Choi G M, et al. Utilization of wood biomass char in a direct carbon fuel cell (DCFC) system. Appl Energ 2013; 105: 207-16.

[20]Cherepy N J, Krueger R, Fiet K J, Jankowski A F, Cooper J F. Direct conversion of carbon fuels in a molten carbonate fuel cell. J Electrochem Soc 2005; 152: A80-A7.

[21]Dudek M, Tomczyk P, Socha R, Hamaguchi M. Use of ash-free "Hyper-coal" as a fuel for a direct carbon fuel cell with solid oxide electrolyte. Int J Hydrogen Energy 2014; 39: 12386-94.

[22]Elleuch A, Boussetta A, Halouani K, Li Y. Experimental investigation of Direct Carbon Fuel Cell fueled by almond shell biochar: Part II. Improvement of cell stability and performance by a three-layer planar configuration. Int J Hydrogen Energy 2013; 38: 16605-14. 
[23]Jewulski J, Skrzypkiewicz M, Struzik M, Lubarska-Radziejewska I. Lignite as a fuel for direct carbon fuel cell system. Int J Hydrogen Energy 2014; 39: 21778-85.

[24]Vutetakis D G, Skidmore D R, Byker H J. Electrochemical Oxidation of Molten Carbonate-Coal Slurries. J Electrochem Soc 1987; 134: 3027-35.

[25]Chen M M, Wang C Y, Niu X M, Zhao S, Tang J, Zhu B. Carbon anode in direct carbon fuel cell. Int J Hydrogen Energy 2010; 35: 2732-6.

[26]Jiang C R, Irvine J T S. Catalysis and oxidation of carbon in a hybrid direct carbon fuel cell. J Power Sources 2011; 196: 7318-22.

[27]Li S B, Pan W Z, Wang S R, Meng X, Jiang C R, Irvine J T S. Electrochemical performance of different carbon fuels on a hybrid direct carbon fuel cell. Int J Hydrogen Energy 2017; 42: 16279-87. [28]Jiang C R, Ma J J, Bonaccorso A D, Irvine J T S. Demonstration of high power, direct conversion of waste-derived carbon in a hybrid direct carbon fuel cell. Energy Environ Sci 2012; 5: 6973-80.

[29]Bonaccorso A D, Irvine J T S. Development of tubular hybrid direct carbon fuel cell. Int J Hydrogen Energy 2012; 37: 19337-44.

[30]Nurnberger S, Bussar R, Desclaux P, Franke B, Rzepka M, Stimming U. Direct carbon conversion in a SOFC-system with a non-porous anode. Energy Environ Sci 2010; 3: 150-3.

[31]Kulkarni A, Giddey S, Badwal S P S. Electrochemical performance of ceria-gadolinia electrolyte based direct carbon fuel cells. Solid State lonics 2011; 194: 46-52.

[32]Kim J-P, Lim H, Jeon C-H, Change Y-J, Kohm K-N, Choi S-M, et al. Performance evaluation of tubular fuel cells fuelled by pulverized graphite J Power Sources 2010; 195: 7568-73.

[33]Kivisaari T, Bjornbom P, Sylwan C, Jacquinot B, Jansen D, De Groot A. The feasibility of a coal gasifier combined with a high-temperature fuel cell. Chem Eng J 2004; 100: 167-80.

[34]Fuente-Cuesta A, Jiang C, Arenillas A, Irvine J T S. Role of coal characteristics in the electrochemical behaviour of hybrid direct carbon fuel cells. Energy Environ Sci 2016; 9: 2868-80.

[35]Tulloch J, Allen J, Wibberley L, Donne S. Influence of selected coal contaminants on graphitic carbon electro-oxidation for application to the direct carbon fuel cell. J Power Sources 2014; 260: 1409.

[36]Zhu Z H, Radovic L R, Lu G Q. Effects of acid treatments of carbon on $\mathrm{N}_{2} \mathrm{O}$ and $\mathrm{NO}$ reduction by carbon-supported copper catalysts.Carbon 2000; 38: 451. 
[37]Xu K, Chen C, Liu H, Tian Y, Li X, Yao H. Effect of coal based pyrolysis gases on the performance of solid oxide direct carbon fuel cells. Int J Hydrogen Energy 2014; 39: 17845-51. 